\section{Nondestructive Acoustic Firmness Tester Detects the Effect of Manure on Muskmelon Texture}

\author{
Muhammad Imran Al-Haq ${ }^{1}$ and Junichi Sugiyama ${ }^{2}$ \\ Radiation \& Information Technology Laboratory, National Food Research \\ Institute, Kannondai 2-1-12, Tsukuba Science City, Ibaraki Prefecture \\ 305-8642, Japan
}

\section{Akiko Tomizawa ${ }^{3}$ and Yasuyuki Sagara ${ }^{4}$ \\ Department of Global Agricultural Sciences, Graduate School of Agricultural \& Life Sciences, The University of Tokyo, Yayoi 1-1-1, Bunkyo-ku, Tokyo 113-8657, Japan}

Additional index words. Cucumis melo, transmission velocity, ultrasonic waves, harvesting time, days after pollination, soluble solid contents, ${ }^{\circ}$ Brix, sweetness, sensory evaluation

\begin{abstract}
The effect of amount of manure (animal dung) on the texture of muskmelons (Cucumis melo L.) has been studied. Melons were grown in a greenhouse with 20 and $50 \mathrm{t} \cdot \mathrm{ha}^{-1}$ of manure. Melons were harvested four times at 4-day intervals and kept at ambient conditions for about 8-12 days. Texture was determined by using "Firm Tester" that employs acoustic technology and to provide a firmness index expressed as transmission velocity [meters per second $(\mathrm{m} / \mathrm{s})]$. At the time of the first, second, third and fourth harvest the fruit grown with $20 \mathrm{t} \cdot \mathrm{ha}^{-1}$ manure gave mean transmission velocities of $\mathbf{5 4 . 5}$ $\pm \mathbf{2 . 5}, \mathbf{5 5 . 2} \pm \mathbf{5 . 7}, \mathbf{4 9 . 6} \pm \mathbf{4 . 8}$, and $46.8 \pm 9.4 \mathrm{~m} / \mathrm{s}$, respectively. Linear regression equations for fruit grown with $20 \mathrm{t} \cdot \mathrm{ha}^{-1}$ manure showed that the fruit from the first harvest took 10 days to reach $40 \mathrm{~m} / \mathrm{s}$, while fruit from the second, third and fourth harvest took 11, 9.5, and 4 days, respectively, to reach this index. The corresponding values for fruit grown in $50 \mathrm{t} \cdot \mathrm{ha}^{-1}$ of manure were 7.5, 10, 5.5 and 4.5 days, those from the second harvest gave the best keeping quality. The firmness index of melon grown in $20 \mathrm{t}^{\cdot h \mathrm{~h}^{-1}}$ of manure was greater than that grown in $50 \mathrm{t} \cdot \mathrm{ha}^{-1}$ manure. Higher soil $\mathrm{NO}_{3}-\mathrm{N}$ contents were associated with softer melons. The correlation between panelist scores for texture and the firmness index was 0.907. Both ${ }^{\circ}$ Brix and panelist scores for sweetness indicated that manure did not affect the sweetness of melon. The digital firmness tester could detect the effect of manure on the texture of the melons, and could be used to determine the appropriate time of harvest for each and every individual melon.
\end{abstract}

Muskmelon is a popular traditional summer fruit in Japan with abundant domestic supply occurring from May through August. The eating quality of this fruit depends largely on harvest of mature melons at the desired stage of ripeness. Generally, optimum eating quality requires adequate sugar and flavor development, and the center meat with a melting texture that progresses to a crisp texture toward the rind. Immature or underripe melons have less sugar and flavor development, and have a firmer texture than those at optimum ripeness.

Flavor and texture degrade dramatically as muskmelons progress from ripe to overripe. It is difficult to judge ripeness by outward charac-

Received for publication 13 Nov. 2002. Accepted for publication 22 Apr. 2003. We thank Abdul Qayyum, for his advice about analysis, and the JACooperative Society of the Asahi village in the Ibaraki Prefecture for provision of melon fruits.

${ }^{1}$ Postdoctoral Fellow. To whom reprint requests should be addressed. Tel. +81-29-8388047, Fax. +81-29-839-1552, E-mail address: imranintokyo@hotmail.com

${ }^{2}$ Head of the laboratory. E-mail address: sugiyama@ affrc.go.jp

${ }^{3}$ Graduate Student.

${ }^{4}$ Professor. teristics such as size, external color, stem condition or feel. General recommendations given to produce managers are that good, ripe melons should be firm, symmetrical, and fresh looking. Determining optimum muskmelon maturity at harvest time, however, is a critical but difficult task, even for experienced growers.

A traditional practice to determine melon texture is to thump or slap the fruit and judge ripeness and defects based on the sound. Material properties of the melon, which change with ripeness, will affect the emitted sound. A hollow, low-pitched sound generally indicates a ripe melon. This is an adequate method only for persons with considerable experience and an objective, nondestructive technique is needed to field test melons for ripeness. Use of such a technique during harvest would help to assure that consistent quality is being delivered to marketers, retailers, and consumers. Sonic and vibration response method is one technique for predicting the textural quality of agricultural products nondestructively. Two basic methods have been explored: 1) resonant frequency (Abbot, 1994; Abbott et al., 1968, 1992; Falk et al., 1958; Finney, 1970, 1971, 1972), and 2) sound velocity (Garrett and Furry, 1972; Sugiyama et al., 1994, 1998).
The principle applied to acquire the resonance of materials is as follows: a vibrator is used to induce a signal in the sample and the response of the material is measured by a sensing device (e.g., an accelerometer) attached to the surface of the product. At each frequency, a specific, inherent peak is observed. This phenomenon is recognized as resonance, and the corresponding frequency as the resonant frequency. The resonant frequency is found to be closely related to the firmness of commodities and is an inherent property of the material. Abbott et al. (1968) and Finney (1971, 1972) developed the methodology for some intact products and reported that $\mathrm{f}^{2} \mathrm{~m}(\mathrm{f}=$ natural frequency, $m=$ mass), which is designated as stiffness coefficient or index of firmness, was highly correlated with texture.

Another method used to determine the resonant frequency is based on response to impact. A microphone takes the place of the accelerometer making noncontact sensing possible, a bell pendulum takes the place of the vibrating system, and the sound can be measured instantaneously (Yamamoto et al., 1980). Yamamoto and Haginuma (1984a, $1984 b, 1984 c)$ reported that sound produced by striking fruit with a wooden hammer and perceived by a microphone, when analyzed by fast Fourier-transformation, could be used to calculate the resonance representing the inherent frequency of apple [Malus $\times$ sylvestris (L.) Mill. var. domestica (Borkh.) Mansf.], watermelon (Citrullus lanatus Thunb.), and radish (Raphanus sativus L.). They compared data with that obtained by conventional compression visco-dynamic methods, and claimed a high correlation. Armstrong et al. (1990) also applied a similar method to apples. The validity of an impact method was further confirmed with pumpkins (Cucurbita pepo L.) and radishes (Chen et al., 1992), and with tomatoes (Lycopersicum esculentum L.) and apples (De Baerdemaeker, 1989). All data correlated with those obtained by a penetrometer. Collectively, all these methods primarily employ resonant frequency in the analysis. Resonant frequencies are affected by the size and shape of the sample. Moreover, the mechanism of producing multiple resonant frequencies in some produce was not clarified by experimental evidence (Sugiyama et al., 1998).

Measurement of sound velocity with ultrasonic waves has also been applied in the evaluation of solid materials (Krautkramer and Krautkramer, 1977). Mizrach et al. (1989) suggested that the velocity of ultrasonic sound could be used for ripeness classification in some fruits and vegetables. Self et al. (1994) showed that the ultrasonic velocity decreased in avocado flesh (Persea americana Mill.) as a function of ripening stage. Zebrowski (1992) also applied the ultrasonic method to measure the stiffness of stem and leaf sheaths of triticale (xTritiosecale). However, in most of these ultrasonic measurements, the attenuation coefficient was extremely high because of the amorphous nature of fruit and vegetable tissues (Mizrach et al., 1989; Sarker and Wolfe, 1983). Therefore, it is difficult to reliably measure the velocity of ultrasonic sound through these 
commodities. Generally, the attenuation coefficient decreases as the frequencies imposed on the material are lowered. Thus, relatively low frequencies (audible range) were applied for evaluation of texture of fruit. As a consequence, Muramatsu et al. (1996) demonstrated that changes in phase of transmitted sound could be readily determined and used as a firmness index. Sugiyama et al. (1994) stated that utilization of the transmission velocity as a measure of firmness has two major advantages over resonance frequency technique, viz., the transmission velocity method compensates for variations in the size of the samples, because the circumference of the sample is included in the calculation, and it is easy to detect the maximum peak in the impact waveform for calculation of transmission velocity (Sugiyama et al., 1998).

It is a well-known that $\mathrm{NO}_{3}-\mathrm{N}$ application can increase yield. A rate of $20 \mathrm{t} \cdot \mathrm{ha}^{-1}$ manure is commonly used commercially, and an experiment was designed to use $20 \mathrm{t} \cdot \mathrm{ha}^{-1}$ manure obtained from animal dung and compare it with $50 \mathrm{t} \cdot \mathrm{ha}^{-1}$. We knew that application of more $\mathrm{NO}_{3}-\mathrm{N}$ will results in more fruit but the main aim was to compare the texture quality of melon produced with these two manure rates.

The objectives of the study were to determine the effect of manure on the texture of melons by nondestructive impulse parameters as indicators of muskmelon ripeness, and to compare it with the results obtained by sensory evaluation.

\section{Materials and Methods}

Fruit material. Melon, cv. Takami, was grown on ground beds in a greenhouse in the Asahi village of Ibaraki Prefecture of Japan. The amount of manure (animal's dung) used was the conventional rate of $20 \mathrm{t} \cdot \mathrm{ha}^{-1}$, treated as control, and compared with $50 \mathrm{t} \cdot \mathrm{ha}^{-1}$. The $\mathrm{NO}_{3}-\mathrm{N}$ contents determined by soil analysis are shown in Table 1 . The plants were transplanted on 25 Mar. 2002, and were pollinated on 4 May 2002. Melons were hand picked. They were harvested four times at 4-d intervals, and were designated as groups A to D. The date of harvest and days after pollination are given in Table 2. After harvesting, melons were transported to the National Food Research Institute, Tsukuba Science City, Ibaraki Prefecture, Japan, for the study. They were kept in ambient conditions.

Nondestructive determination of texture. Texture was determined by using Firm Tester (model SA-1; Toyo Seiki Co., Tokyo) that employs acoustic technology and gives digital readings of transmission velocity [meters per second $(\mathrm{m} / \mathrm{s})$ ] as a firmness index. The instru-

Table $1 . \mathrm{NO}_{3}-\mathrm{N}$ content in the soil of the treatments in the greenhouse of the Asahi village in the Ibaraki prefecture, Japan.

\begin{tabular}{lcc}
\hline & \multicolumn{2}{c}{$\mathrm{NO}_{3}-\mathrm{N}$ in soil surface } \\
\cline { 2 - 3 } $\begin{array}{c}\text { Manure } \\
\left(\mathrm{t} \cdot \mathrm{ha}^{-1}\right)\end{array}$ & $\begin{array}{c}\text { Surface } \\
\text { up to } 19 \mathrm{~cm} \\
(\mathrm{mg} \text { per } 100 \mathrm{~g})\end{array}$ & $\begin{array}{c}\text { Subsurface } \\
\text { up to } 28 \mathrm{~cm} \\
(\mathrm{mg} \text { per } 100 \mathrm{~g})\end{array}$ \\
20 & 71.2 & 47.4 \\
50 & $>100$ & 62.4 \\
\hline
\end{tabular}

Table 2. Harvest groups, date of harvest, manure rate and their regression equations for firmness of melons treated with 20 and $50\left(\mathrm{t} \cdot \mathrm{ha}^{-1}\right)$ manure.

\begin{tabular}{lccccc}
\hline Group & $\begin{array}{c}\text { Date of } \\
\text { harvest }\end{array}$ & $\begin{array}{c}\text { Days after } \\
\text { pollination }\end{array}$ & $\begin{array}{c}\text { Manure } \\
\left(\mathrm{t} \cdot \mathrm{ha} \mathrm{a}^{-1}\right)\end{array}$ & $\begin{array}{c}\text { Regression } \\
\text { equation }^{2}\end{array}$ & $R^{2}$ \\
\hline A & 3 July & 59 & 20 & $\mathrm{Y}=55.72-1.55 \mathrm{x}$ & 0.964 \\
& & & 50 & $\mathrm{Y}=52.93-1.62 \mathrm{x}$ & 0.970 \\
B & 7 July & 63 & 20 & $\mathrm{Y}=57.30-1.56 \mathrm{x}$ & 0.983 \\
& & & 50 & $\mathrm{Y}=55.06-1.49 \times$ & 0.966 \\
C & 11 July & \multirow{2}{*}{67} & 20 & $\mathrm{Y}=52.42-1.19 \mathrm{x}$ & 0.995 \\
& & & 50 & $\mathrm{Y}=52.75-2.34 \mathrm{x}$ & 0.985 \\
D & \multirow{2}{*}{71} & 20 & $\mathrm{Y}=49.76-2.60 \mathrm{x}$ & 0.945 \\
& 15 July & & 50 & $\mathrm{Y}=56.92-3.30 \mathrm{x}$ & 0.991 \\
\hline
\end{tabular}

${ }^{\mathrm{z}} \mathrm{Y}=$ Firmness index as transmission velocity $(\mathrm{m} / \mathrm{s}) ; \mathrm{x}=$ storage period (days).

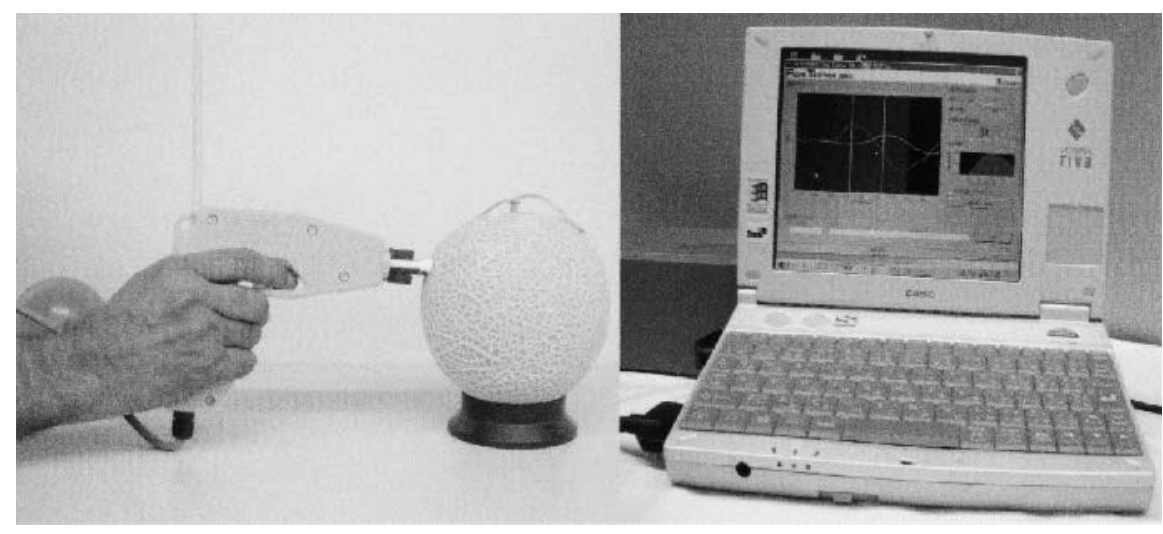

Fig.1. Firm tester for measuring the transmission velocity (meters per second) of muskmelon with a depiction of results on a computer.

ment (Fig. 1) consists of an impulse generator, an amplifier, a PC card [Analog/Digital (A/D) converter], and a personal computer (PC). Pulling the trigger of the firmness tester starts the measurement and the result appears on the PC screen in less than a second (Fig. 1). The impact rod and the two microphones are in line with each other. For melons, the microphones were set at $16 \mathrm{~mm}$ apart from each other. The vibration produced by the impact is transmitted in all directions on the surface of the sample. Two microphones detect the traveling vibrations as sound signals. Due to $16 \mathrm{~mm}$ separation between the microphones, there is a slight time difference in their detection of sound signals. The sound signals are amplified and transmitted to the computer through an A/D converter. The sampling frequency was selected to 200 $\mathrm{kHz}$ per channel. Four locations on each melon were marked and the transmission velocity at them was measured. The melons were rotated in-place to have an access to alternate locations. The average of four points was calculated and used as a nondestructive firmness index. Each treatment had four replications.

Destructive analysis. Melon were cut into 12 equal pieces. Two pieces (opposite to each other) were separated for soluble solid contents (SSC, ${ }^{\circ}$ Brix) assay, while the remaining pieces were used for sensory evaluation. To obtain the sample for SSC assay, a core borer was inserted in the equatorial sections of melon to avoid stem-end to blossom-end gradients. The rind was separated with a knife and the remaining cylinder was squeezed to obtain juice, which was tested using a digital refractometer (model PR-100, ATAGO, Tokyo).
Sensory evaluation. The sensory panel comprised of nine untrained judges from National Food Research Institute, who frequently consume muskmelons. They were briefed about how to score for firmness and sweetness on a hedonic scale from 1 (extremely soft or dislike extremely) to 7 (extremely hard or like extremely).

Experimental design and statistical analysis. Linear regression lines were fitted to the transmission velocity data by using Microsoft Excel 2000. The data obtained through sensory evaluation and SSC contents were subjected to analysis of variance. The experimental design was split plot in a randomized complete-block design. The four harvests and three storage intervals were taken as main plot and in subsplot 2 levels of manure dose were taken. The means were compared by the Duncan's Multiple Range (DMR) test at $P \leq 0.05$ by MSTAT-C software (Michigan State Univ., E. Lansing).

\section{Results}

Nondestructive texture assessment by digital firmness tester. Low and high transmission velocities indicate soft and hard fruit, respectively. The relationship between transmission velocity and storage days was nearly linear (Fig. 2). Melons grown in $20 \mathrm{t} \cdot \mathrm{ha}^{-1}$ manure had higher velocities than those grown in $50 \mathrm{t}^{\mathrm{h}} \mathrm{ha}^{-1}$ manure. Hence, the $50 \mathrm{t} \cdot \mathrm{ha}^{-1}$ manure treatment produced softer melons than $20 \mathrm{t} \cdot \mathrm{ha}^{-1}$ manure treatment (Fig. 2). Melons harvested on July 3 (Group A) had a velocity of $54.5 \pm 2.5 \mathrm{~m} / \mathrm{s}$, July 7 (Group B) had a velocity of $55.7 \pm 5.7$, 


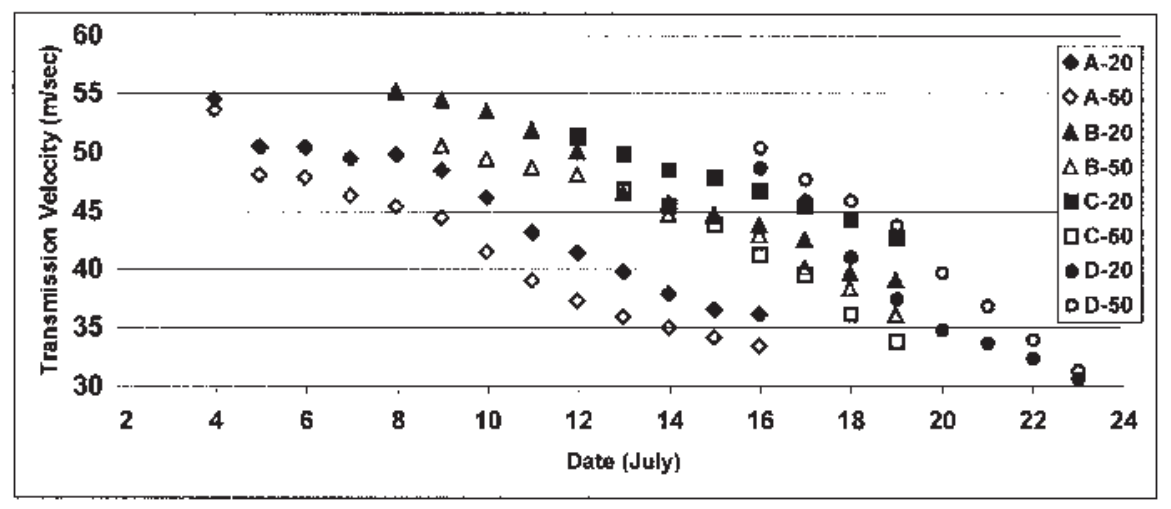

Fig. 2. Fruit firmness judged by the firmness index (transmission velocity, meters per second) for four harvested groups (A to D) of melons treated with 20 (solid symbols) and 50 (hollow symbols) tha ${ }^{-1}$ of manure.

whereas groups $\mathrm{C}$ and $\mathrm{D}$ had velocities of 49.60 \pm 4.8 , and $46.8 \pm 9.4 \mathrm{~m} / \mathrm{s}$, respectively. Hence, the slowest velocity was recorded for those harvested on July 15 (Group D) and the most firm were those harvested $63 \mathrm{~d}$ after pollination (group B) (Fig. 2). The regression coefficient (slope) of each regression equation shows a reduction in the velocity per day (Table 2 ). It is evident that reduction in melons from the 50 $\mathrm{t} \cdot \mathrm{ha}^{-1}$ treatment was greater than that observed for $20 \mathrm{t} \cdot \mathrm{ha}^{-1}$ treatment (Table 2).

Sensory scores for texture. Sensory panelists scores were affected by harvest time, storage interval, and manure dose (Table 3 ). The panelists awarded higher texture scores for melons grown in $20 \mathrm{t} \cdot \mathrm{ha}^{-1}$ manure compared with $50 \mathrm{t} \cdot \mathrm{ha}^{-1}$ manure, indicating that the higher manure treatment resulted in softer melons (Table 3). It conforms to the data taken by the digital firmness tester. The regression analysis gave $R^{2}$ of 0.8226 with the regression equation $\mathrm{y}=8.3407 \mathrm{x}+18.329$. There was a high level of correlation $(r=0.907)$.

Soluble solid contents (SSC). The effect of harvest time on SSC was significant but not the effect of storage interval and manure dose (Table 4).

Sensory scores for sweetness. Scores for sweetness awarded by panelists were affected significantly by harvest time and storage interval, but not by manure dose (Table 5).

\section{Discussion}

The acoustic data derived in this experiment demonstrate that the transmission velocity, or firmness index, of melons grown in 20 $\mathrm{t} \cdot \mathrm{ha}^{-1}$ was higher than those grown in $50 \mathrm{t} \cdot \mathrm{ha}^{-1}$ manure. Melons from the highest manure rate were softest. Sugiyama et al. (1994) reported that higher transmission velocity depicts firmer melons. Previous reports on the ultrasound velocity transmit through melons were similar to our results. Mizrach et al. (1994) measured the transmission velocity of ultrasound at $50,000 \mathrm{~Hz}$ in melons $\mathrm{cv}$. Galia ranging from 60 to $80 \mathrm{~m} / \mathrm{s}$. In our study, the fruit were harvested on a certain date and not in accordance with their maturity stage, as our focus was on obtaining differences in melon texture for analysis.
Linear models for all lines were significant $(P<0.001)$ and explained more than $94 \%$ of the variability in texture of melons (Table 2 ). A perusal of the linear models depict that the first, second, third and fourth harvested melons grown in $20 \mathrm{t}^{\circ} \mathrm{ha}^{-1}$ manure took $10,11,9.5$, and $4 \mathrm{~d}$, respectively, to reach $40 \mathrm{~m} / \mathrm{s}$. In contrast, the first harvest of melons grown in $50 \mathrm{t} \cdot \mathrm{ha}^{-1}$ manure took $7.5 \mathrm{~d}$ to reach $40 \mathrm{~m} / \mathrm{s}$, and the second, third and fourth harvest took 10, 5.5, and $4.5 \mathrm{~d}$, respectively. Accordingly, harvesting $63 \mathrm{~d}$ after pollination (second harvest or group B) gave the maximum keeping quality and with firmer melons (Fig. 2, Table 2). Sugiyama et al. (1998) harvested melons $61 \mathrm{~d}$ after pollination and reported that the transmission velocity began to decrease quickly. They further reported that the best eating quality occurs when transmission velocity is between 45 and $58 \mathrm{~m} / \mathrm{s}$.

Firmness of $20 \mathrm{t} \cdot \mathrm{ha}^{-1}$ manure-grown melons for group $\mathrm{D}$ was lower than that of melons of the earlier three groups, viz. A, B, and C (Fig. 2). The group contained many diseased melons making it difficult to obtain the required number of samples for the experiment. Interestingly, the $50 \mathrm{t}^{\mathrm{h}} \mathrm{ha}^{-1}$ treated melons were less diseased affected than $20 \mathrm{t} \cdot \mathrm{ha}^{-1}$ in group D.

Group D showed symptoms of internal breakdown. The precise factors governing this condition are unknown; however, they are thought to be attributed to over ripening of the fruit flesh (Mizrach et al., 1994). Even if the fruit has internal disorders the external peel remains green or light yellow - the disorder is undetectable without first cutting open the melon. Afflicted melons, included accidentally within export shipments, can burst in transit, showering all surrounding fruits with their contents, and thereby becoming a rich source of fungal pathogens (Mizrach et al., 1994).

It was expected that more manure would result in sweeter melons, but data did not show a clear trend (Table 4). Groups A, B, and D grown in $50 \mathrm{t} \cdot \mathrm{ha}^{-1}$ manure were sweeter, but in the group $\mathrm{C}$ fruit grown in $20 \mathrm{t} \cdot \mathrm{ha}^{-1}$ manure were sweeter than those grown in $50 \mathrm{t} \cdot \mathrm{ha}^{-1}$ manure. The results indicate that the amount of manure is not responsible for sweetness. Evensen (1983) stated that SSC slightly declined or did not change during storage at 0 and $4.5^{\circ} \mathrm{C}$ plus
Table 3. Sensory evaluation for texture of melons treated with 20 and $50 \mathrm{t} \cdot \mathrm{ha}^{-1}$ manure, harvested four times, and evaluated at three storage intervals.

\begin{tabular}{lccccc}
\hline $\begin{array}{l}\text { Days after } \\
\text { harvest }\end{array}$ & $\begin{array}{c}\text { Manure } \\
\left(\mathrm{t} \cdot \mathrm{ha}^{-1}\right)\end{array}$ & \multicolumn{4}{c}{ Scores $^{\mathrm{z}}$ for harvest groups } \\
\cline { 2 - 6 } & 20 & $\mathrm{~A}$ & $\mathrm{~B}$ & $\mathrm{C}$ & $\mathrm{D}$ \\
\hline 1 & 50 & 4.61 & 4.56 & 4.44 & 4.33 \\
& 20 & 4.00 & 3.83 & 3.17 & 3.67 \\
5 & 50 & 2.50 & 3.39 & 2.67 & 3.39 \\
& 20 & 2.67 & 2.83 & 2.61 & 3.50 \\
9 & 50 & 2.17 & 2.50 & 2.56 & 2.24
\end{tabular}

LSD 0.57

Analysis of variance ( $\mathrm{F}$ probability) Manure Dose (D)

Harvest Time $(\mathrm{H})$

$\mathrm{D} \times \mathrm{H}$

Storage Interval (I)

$\mathrm{D} \times \mathrm{I}$

$\mathrm{H} \times \mathrm{I}$

0.0000

0.0156

NS

0.0000

0.0035

$\mathrm{D} \times \mathrm{H} \times \mathrm{I}$

${ }^{\text {}}$ Hedonic taste scores were awarded on a scale of 1 (dislike extremely) to 4 (neither dislike nor like) to 7 (like extremely).

${ }^{\mathrm{N}}$ Nonsignificant.

Table 4. Soluble solid contents (SSC, ${ }^{\circ}$ Brix) of melons treated with 20 and $50 \mathrm{t} \cdot \mathrm{ha}^{-1}$ manure, harvested four times, and evaluated at three storage intervals.

\begin{tabular}{lccccc}
\hline Days after & \multicolumn{4}{c}{$\begin{array}{c}\text { Manure } \\
\text { harvest }\end{array}$} & \multicolumn{4}{c}{${ }^{\circ}$ Brix for harvest groups } \\
\cline { 2 - 6 }$\left(\mathrm{t} \cdot \mathrm{ha}^{-1}\right)$ & $\mathrm{A}$ & $\mathrm{B}$ & $\mathrm{C}$ & $\mathrm{D}$ \\
\hline 1 & 20 & 10.15 & 10.82 & 11.53 & 11.95 \\
& 50 & 11.95 & 11.62 & 13.20 & 10.60 \\
5 & 20 & 11.68 & 11.28 & 12.69 & 12.00 \\
& 50 & 11.19 & 10.80 & 13.90 & 11.02 \\
9 & 20 & 10.91 & 11.32 & 14.17 & 12.55 \\
& 50 & 10.55 & 11.27 & 12.75 & 11.55
\end{tabular}

LSD 1.32

Analysis of variance ( $\mathrm{F}$ probability)

Manure Dose (D)

Harvest Time $(\mathrm{H})$

$\mathrm{D} \times \mathrm{H}$

Storage Interval (I)

$\mathrm{D} \times \mathrm{I}$

$\mathrm{H} \times \mathrm{I}$

NS

0.0000

0.0046

NS

NS

NS

$\mathrm{D} \times \mathrm{H} \times \mathrm{I}$

0.0116

Ns Nonsignificant.

Table 5. Sensory evaluation for sweetness of melons treated with 20 and $50 \mathrm{t} \cdot \mathrm{ha}^{-1}$ manure, harvested four times, and evaluated at three storage intervals.

\begin{tabular}{lccccc}
\hline $\begin{array}{l}\text { Days after } \\
\text { harvest }\end{array}$ & $\begin{array}{c}\text { Manure } \\
\left(\mathrm{t} \cdot \mathrm{ha}^{-1}\right)\end{array}$ & \multicolumn{4}{c}{ Scores $^{\mathrm{z}}$ for harvest groups } \\
\cline { 2 - 6 } & 20 & $\mathrm{~A}$ & $\mathrm{~B}$ & $\mathrm{C}$ & $\mathrm{D}$ \\
\hline 1 & 50 & 5.33 & 5.17 & 5.06 & 4.17 \\
& 20 & 4.89 & 5.44 & 4.67 & 4.28 \\
5 & 50 & 5.28 & 4.83 & 5.78 & 4.78 \\
& 20 & 4.89 & 5.00 & 5.39 & 3.11 \\
9 & 50 & 4.44 & 4.83 & 4.83 & 3.28 \\
& & \multicolumn{4}{c}{0.633}
\end{tabular}

Analysis of variance ( $F$ probability)

Manure Dose (D)

Harvest Time $(\mathrm{H})$

$\mathrm{D} \times \mathrm{H}$

Storage Interval (I)

0.0000

$\mathrm{D} \times \mathrm{I}$

NS

$\mathrm{H} \times \mathrm{I}$

0.0000

0.0088

$\mathrm{D} \times \mathrm{H} \times \mathrm{I}$

0.0027

${ }^{\text {zHedonic sweetness scores were awarded on a scale }}$ of 1 (dislike extremely) to 4 (neither dislike nor like) to 7 (like extremely). 
one day at $13{ }^{\circ} \mathrm{C}$. The ${ }^{\circ}$ Brix in the blossom end is about twice as high as in the stem end (Ishigami and Matsuura, 1993; Mizuno et al., 1971).

Sensory evaluation scores for texture showed high correlation $(r=0.907)$ with the transmission velocity and validated the study.

In summary, the digital firmness tester could detect the effect of manure on the texture of the melons, and can be used to determine the appropriate time of harvest for each and every individual melon.

\section{Literature Cited}

Abbott, J.A., G.S. Bachman, N.F. Childers, J.V Fitzgerald, and K.F. Matsusik. 1968. Sonic techniques for measuring texture of fruits and vegetables. Food Technol. 22:635-646.

Abbott, J.A., H.A. Affeldt, and Liljedahl. 1992. Firmness measurement of stored 'delicious' apples by sensory method, Magness-Taylor, and sonic propagation. J. Amer. Soc. Hort. Sci. 117:590-595

Abbott, J.A. 1994. Firmness measurement of freshly harvested 'Delicious apple' by sensory method, sonic transmission, Magness-Taylor, and compression. J. Amer. Soc. Hort. Sci. 119: 510-515.

Armstrong, P., H.R. Zapp, and G.K. Brown. 1990. Impulsive excitation of acoustic vibrations in apples for firmness determination. Trans. ASAE 33:1353-1359.

Chen, P., Z. Sun, and L. Huang. 1992. Factors affecting acoustic responses of apples. Trans. ASAE 35:1915-1920.
De Baerdemaeker, J. 1989. The use of mechanical resonance measurements to determine fruit texture. Acta Hort. 258:331-339.

Evensen, K.B. 1983. Effects of maturity at harvest, storage temperature, and cultivar on muskmelon quality. HortScience 18:907-908.

Falk, S., C.H. Hertz, and H.I. Virgin. 1958. On the relation between turgor pressure and tissue rigidity. Physiol. Plant 11:802-817.

Finney,E.E. 1970. Mechanical resonance within Red Delicious apples and its relation to fruit texture. Trans. ASAE 13:177-180.

Finney, E.E. 1971. Dynamic elastic properties and sensory quality of apple fruit. J. Texture Studies 2:62-74.

Finney, E.E. 1972. Vibration techniques for testing fruit firmness. J. Texture Studies 3:263-283.

Garrett, R.E. and R.B. Furry. 1972. Velocity of sonic pulses in apples. Trans. ASAE 15:770-774.

Ishigami, K. and H. Matsuura. 1993. Bull (in Japanese). Shizuoka Agr. Expt. Sta. 37:33-40 .

Krautkramer, J. and H. Krautkramer. 1977. Ultrasonic testing of materials. Springer-Verlag, Berlin.

Mizuno, T., K. Kato, M. Harada, Y. Miyajima, and E. Suzuki. 1971. Studies on the free sugars and amino acids in a fruit of Muskmelon (in Japanese with English summary, figures, and tables). Nippon Shokuhin Kagaku Kogaku Kaishi 18:319-325.

Mizrach, A., N. Galili, and G. Rosenhouse. 1989. Determination of fruit and vegetable properties by ultrasonic excitation. Trans. ASAE 32: 2053-2058.

Mizrach, A., N. Galili, D.C. Teitel, and G. Rosenhouse. 1994. Ultrasonic evaluation of some ripening parameters of autumn and winter-grown 'Galia' melons. Scientia Hort. 56:291-297.

Muramatsu, N., N. Sakurai, R. Yamamoto, and D.J. Nevins. 1996. Nondestructive acoustic measure- ment of firmness for nectarines, apricots, plums, and tomatoes. HortScience 31:1199-1202.

Sarker, N. and R.R. Wolfe. 1983. Potential of ultrasonic measurement in food quality evaluation. Trans. ASAE 26:264-629.

Self, G.K., E. Ordogoti, M.J.W. Povey, and H Wainwright. 1994. Ultrasonic evaluation of ripening avocado flesh. Postharvest Biol. Technol. 4:111-116.

Sugiyama, J., K. Otobe, S. Hayashi, and S. Usui. 1994. Firmness measurement of muskmelons by acoustic impulse transmission. Trans. ASAE 37:1235-1241.

Sugiyama, J., T. Katsurai, J. Hong, H. Koyama, and K. Mikuriya. 1998. Melon ripeness monitoring by a portable firmness tester. Trans. ASAE 41: 121-127.

Yamamoto, H., M. Iwamoto, and S. Haginuma. 1980. Acoustic impulse response method for measuring natural frequency on intact fruits and preliminary applications to internal quality evaluation of apples and watermelons. J. Texture Studies 11:117-136.

Yamamoto, H. and S. Haginuma. 1984a. Estimation of the dynamic Young's modulus of apple flesh from the natural frequency of an intact apple. Rpt. Natl. Food Res. Inst. 44:20-25.

Yamamoto, H. and S. Haginuma. 1984b. Dynamic viscoelastic properties and acoustic properties of watermelons. Rpt. Natl. Food Res. Inst. 44: 30-35.

Yamamoto, H. and S. Haginuma. 1984c. Dynamic viscoelastic properties and acoustic properties of Japanese radish (Shogoin) roots. Rpt. Natl. Food Res. Inst. 44:36-44.

Zebrowski, J. 1992. Complementary patterns of stiffness in stem and leaf sheats of Triticale. Planta 187:301-305 